\title{
Sexualidades kanhgág e algumas de suas potencialidades no domínio da afinidade potencial
}

\author{
LUCAS CIMBALUK
}

INSTITUTO DO PATRIMÔNIO HISTÓRICO E ARTÍSTICO NACIONAL (IPHAN), FLORLANÓPOLIS/SC, BRASIL HTTPS://ORCID.ORG/OOOO-0002-5I83-034I

\section{Introdução}

O percurso das análises em torno da sexualidade na antropologia é de longa data. Temos, por exemplo, trabalhos de Malinowski (1932; 2013), que trouxeram controvérsia ao descrever entendimentos de geração de filhos desvinculados do sexo nas Ilhas Trobriand, e que, em debate com Freud, buscou indicar as diferenças sociológicas que implicam em diferenças nos "complexos" psicológicos gerados no núcleo familiar. Outra referência é Margareth Mead (1979) que traçou uma diferenciação entre sexos e sua associação a temperamentos determinados culturalmente. $\mathrm{Na}$ discussão estruturalista, como em Lévi-Strauss (1982), a sexualidade ficou subordinada à discussão da troca de mulheres e da proibição do incesto como regra social universal primordial. $\mathrm{O}$ debate feminista posterior, buscou indicar o caráter cultural da própria definição de gênero, contra a noção de reflexos de dados biológicos universais e irredutíveis. Podemos destacar ainda, na sequência, o trabalho de Strathern (2006) na desconstrução do caráter fixo de papéis sexuais, de homem/mulher, macho/fêmea, investindo na caracterização das formas de construção da pessoa (para um resumo bastante sintético deste histórico ver Almeida 2003).

Nos estudos sobre povos indígenas das terras baixas da América do Sul, como destaca Belaunde (2015a), o tema da sexualidade data ao menos dos anos 1950, tendo importante inflexão com o trabalho de Siskind (1973) ao introduzir na clássica discussão da troca, o sexo como elemento na relação. A partir dos anos 1980, como referência central destes trabalhos podemos destacar a noção de construção da pessoa na proposta de Seeger, DaMatta e Viveiros de Castro (1979). Tal proposta coloca no centro a questão do corpo e corporalidade e sua construção social, sobressaindo-se às definições prévias clássicas de clãs e linhagens abordadas em estudos africanistas. Avançando neste caminho, com 
foco na especificidade da constituição dos coletivos e grupos sociais, em especial o parentesco, temos proposições gerais bastante contrastantes. Por um lado, a que veio a ser conhecida como "economia simbólica da alteridade", com foco no fundo de afinidade que seria prevalente e dado no mundo ameríndio, contra o qual se construiria o parentesco; por outro lado, a "economia moral da intimidade", com foco no cotidiano, na estética da vida social e nos domínios de intimidade dos consanguíneos (para uma proposta de equalização destas abordagens ver McCallum 2013). Trabalhos como os de McCallum (1994), Belaunde (2015b), Pissolato (2015) e Lasmar (2005) entre outros, representam diferentes abordagens do desenvolvimento destas propostas teóricas, voltando-se a discussões sobre sexo e sexualidade, tendo como referência diferentes contextos etnográficos, pensando a sexualidade como elemento constituinte do processo de criação de relações sociais, construção de pessoas, e da relação com a alteridade.

Inspirado em alguns desses trabalhos, proponho aqui a abordagem da relação sexual em alguns contextos específicos kanhgág ${ }^{1}$ em que se coloca como uma forma de relação com a alteridade ${ }^{2}$. Mais especificamente das relações com aquilo que poderíamos denominar de afins potenciais, seguindo as definições de Viveiros de Castro (2000). Inspiram-me aqui sobretudo as relações estabelecidas com os não indígenas, os brancos, em casos em que estas relações não geram casamentos, ou ao contrário, visam o casamento com mudança de residência para fora da aldeia.

Tenho como referência, de um lado, a definição do corpo como matriz de símbolos e objeto de pensamento ameríndio, conforme a mencionada proposição de Seeger, DaMatta e Viveiros de Castro (1979). De outro lado, tomo a discussão dos processos de consanguinização e afinização entendidos como constituintes tanto da construção da pessoa a partir da corporalidade indígenas como da produção da coletividade (Viveiros de Castro 1996; 2000), entendendo esta coletividade enquanto composição cosmopolítica. Nesta proposta, os "afetos" informam o ponto de vista de humanidade do sujeito a partir de seu corpo. Afetos, neste sentido, significam as afecções ou capacidades que singularizam os corpos: o que come, como se move, como se comunica, onde vive, etc. (Viveiros de Castro 1996: 128). Assim sendo, indicam sua posição de humanidade a partir de suas características corpóreo-afetivas. Sexo e sexualidade, enquanto afetos, entram, desta maneira, como elementos que produzem e deslocam alteridades e diferenças, tanto no nível humano como não humano, produzindo parentesco e corpos, com possibilidade de mudanças de ponto de vista a partir tanto da troca de substâncias envolvida, como pela posição relacional entre os envolvidos. Podem conformar as oposições nós/eles, consanguíneos/afins, definindo grupos a partir de políticas, neste caso, sexuais. E, de outro lado, produzem pessoas a partir de suas características particulares, no que chamaríamos de gênero. Desta forma, pode-se afastar concepções ocidentais de pessoa enquanto definida por identidade sexual, com base na noção de sujeito de direito, indivíduo, proprietário e autônomo em sua vontade, por exemplo, para pensar a

1 Utilizo a grafia kanhgág, que é a que vem sendo adotada contemporaneamente por alguns de meus interlocutores, em vez da mais usual kaingang.

2 Versão anterior deste trabalho foi apresentada na XI Conferência sesquianual da SALSA - Society for the Anthropology of Lowland South America - ocorrida em Lima, Peru, em julho de 2017. Agradeço aos colegas do Núcleo de Estudos Ameríndios (NEA)/UFPR pelas discussões sobre outra versão deste trabalho, que trouxeram importantes transformações de minha perspectiva sobre o tema. Agradeço muito especialmente à leitura criteriosa e crítica feita por Flávio Wiik, que fez valiosas contribuições e sugestões, que pude incorporar, no entanto, menos do que gostaria. Também os pareceristas da Campos contribuíram muito gentilmente. Os equívocos são todos meus. 
sexualidade associada aos trânsitos e as mudanças contextuais e produzidas entre as posições relacionais. Tais posições, como veremos, podem dizer respeito tanto às de homem/mulher, macho/fêmea, como também a de indígena/mestiço/não indígena.

Tenho aqui o sexo como constituinte da consanguinização de parentes, produção de pessoas e corpos de parentes, mas procuro explorá-lo, ao contrário, nos casos em que se dá nos perigosos contextos dos não parentes, não consanguíneos ou afins efetivos onde então temos jogos ambíguos entre predação e consanguinização.

É muito importante destacar que minha perspectiva, além de minha própria vivência nas aldeias, parte da captura de comentários e histórias, sobretudo de homens mais velhos, mais do que inquirindo sobre seus sentidos. Não tanto pela dificuldade de tratar o tema a não ser em situações jocosas, mas pelo meu próprio posicionamento e condição em campo, que informa também minha perspectiva. Entendo que a experiência por que passa o pesquisador em campo, além de estabelecer relacionalidade na pesquisa, deve ser interessante na medida em que possa fazer refletir e explorar as possibilidades de alteridade motivadas por sua presença enquanto "outro" para aqueles com quem trabalha, já que ele também os considera em alguma medida "outros". A sexualidade entra como um dos elementos a ser pensado a partir da experiência do etnógrafo, uma vez que é um dos constituintes da existência humana (e para que seja considerado como humano, considerando-se seus afetos). Por esta forma de abordagem, ressalto, não se trata de fazer um mapeamento sistemático e definitivo de práticas e de sua articulação sociocósmica ou chegar a um padrão ou descrição geral de comportamento ou cultura "Kaingang”. O que procuro é indicar para algumas possibilidades a partir de determinados "casos" kanhgág. O artigo é, assim, em boa medida uma espécie de "caso" ele mesmo.

Tratarei especialmente de algumas situações limite e algumas alternativas de relação com os não indígenas principalmente, que apontam para diferentes maneiras de operar os processos de consanguinização e indianização do Outro, ou devir branco às vezes aparentemente deliberado, incluindo atores que parecem conseguir transitar entre estes movimentos, aparentando transcendê-los. Parto do contexto da "bagunça" dos bares e bailes. Trato de alguns sentidos do ato sexual para avaliar como ele opera relações com o Outro, pensando as posições relacionais entre os envolvidos a partir da economia das trocas. Abordo as situações de não casamento por algumas mulheres que podem passar por relações com não indígenas, pensando as implicações da posição de uma maior alteridade nestas relações. Relato casos de casamentos com brancos e as possibilidades de indianização do branco ou devir branco e suas ambiguidades e possibilidades a partir de visões que podem desafiar o que entendemos por "vontade" e a autonomia da pessoa, em relações que podem mudar a perspectiva do sujeito a partir de seus afetos. Chego então a discutir, com base comparativa, como esses casos podem operar os processos transformativos relacionais, nunca definitivos, entre consanguinização e afinização.

O trabalho tem como base pesquisas de campo realizadas por mim entre os anos de 2012 e 2015 em Terras Indígenas (TI) da região da bacia do rio Tibagi, localizada no norte do Estado do Paraná, nas quais estive pesquisando de maneira muito desigual. São cinco TI de relativamente pequena extensão territorial, bastante relacionadas entre si por laços históricos e de parentesco, ainda que difiram, por exem-

3 Optei, no entanto, por não diferenciar os contextos de cada comunidade ou aldeia. 
plo, em população, uso da língua kanhgág e composição étnica, com guarani, xetá e poucas famílias ou indivíduos de outras etnias, ainda que predomine no conjunto a etnia kanhgág, à qual me deterei aqui.

As aldeias, também ditas por vezes pequenas cidades, têm número de habitantes que já chegou em um caso a cerca de $1500 \mathrm{em}$ um passado recente. As maiores aldeias hoje, porém, giram em torno de 500 ou 600 pessoas. São dispostas em ruas compondo núcleos de habitações rodeadas pela área agrícola e mata mais à periferia. Nas aldeias também estão locais de encontro e de construção de sociabilidade mais ampla, como praça, escola, escritório e campos de futebol. Cosmologicamente, podemos identificar, seguindo Robert Crépeau (1997), uma distinção concêntrica casa/limpo/mato virgem, que localiza diferentes espaços (não necessariamente efetivados fisicamente de maneira concêntrica) e configura diferentes escalas de relação. A casa como lugar de habitação, limpo como a área pública e agrícola de entorno e o mato virgem como a área florestal menos acessada.

Desde o início de minha relação com kanhgág na região observei as formas de identificação da indianidade, fundamentais para tratar das formas de caracterização da alteridade. Estas classificações me ativeram mais que as classificações clânicas dualistas, classicamente descritas ao grupo, expressas ali através das marcas corporais (Veiga 1994; 2000). O contexto das TI da região do Tibagi é, em graus diferentes, de uma relação mais ou menos cotidiana com não indígenas, seja na cidade ou mesmo na própria TI, com regionais que ou trabalham nas TI ou residem nas proximidades. Os indígenas, mesmo quando residentes em TI distantes de núcleos urbanos, mantêm com estes relações próximas, sendo comum a presença indígena nas cidades.

Investi (Cimbaluk 2013) em caracterizações sobre quem era ou não indígena na perspectiva de meus interlocutores. Pude desenvolver a partir daí, então, uma noção de gradiente relacional em uma tríade indio puro/mestiço/branco. Estas categorias nativas são frequentemente usadas ao se falar de outros, especialmente quando se está conversando com um pesquisador de fora. Além de relações de filiação, tal identificação era bastante variável de acordo com o contexto de enunciação, podendo tanto o interlocutor identificar-se ou identificar a terceiros diferentemente de acordo com a relação de interlocução e os elementos em questão em determinada situação. Se podemos sob certo ponto de vista afirmar bastante categórica e irredutivelmente a diferença entre quem seja branco e quem seja índio (kanhgág) em determinadas situações, em outros contextos a mestiçagem presente em maiores ou menores graus nas TI da região pode dar margem a avaliações muito divergentes. Local de residência, uso da língua kanhgág, conhecimento e consumo de comidas tradicionais, tempo de convivência, casamentos, geração de filhos, forma de criação destes, relações políticas e o comportamento para com outros também no âmbito da afinidade são elementos gerais que poderiam ser destacados. Chamando a atenção às teorias postuladas aqui, podemos colocar que temos o corpo e a consubstancialidade como elementos fundamentais da produção de parentesco, de corpos de parentes ${ }^{4}$. Diante disso, as classificações não são estanques e são relacionais mesmo dentro da aldeia, sendo definidas muito mais pelas relações que se produzem na coletividade do que por critérios definidos e definitivos.

4 Uma importante análise neste sentido entre kanhgág é feita por Patrícia Carvalho Rosa (2011). 
Assim, no caso da mestiçagem, a própria definição de pertencimento a metades clânicas era desafiada. Na região do Tibagi, expressos os grupos exógamos através de marcas corporais, encontrei posições contraditórias sobre o pertencimento clânico de mestiços, uma vez que prevalece a definição patrilinear do clã e que não indígenas, a princípio, não teriam marcas, apesar de, em certos casos, as adquirirem ao longo de sua convivência com o grupo.

No que tange mais especialmente à temática deste artigo, na caracterização de "mestiço" entrava em questão diretamente o comportamento dos mais novos naquilo que se chamava de "bagunça": as "mestiçadas" não respeitavam mais seus esposos e esposas, ou seja, não mantinham relações de casamento monogâmico com exclusividade sexual. Apesar de esta não ser uma noção generalizada, pois como afirmei, é sempre relacional, mostra como a sexualidade pode ser também um elemento de avaliação das relações atuais e contraste com avaliações de épocas passadas. A afirmação não significa, no entanto, que os jovens sejam sempre consideráveis como mestiços. Trata-se, neste caso, de uma avaliação moral com base em uma noção determinada de parentesco e sexualidade indígena e não indígena.

A dita "bagunça" nestes discursos estava muito relacionada à circulação de jovens de dia e de noite pela aldeia. Era um indicativo de que tais jovens, além de, durante o dia, não trabalharem para sustentar uma potencial família, durante a noite andavam bebendo e mantendo relações sexuais supostamente com diferentes parceiros, sem a perspectiva do casamento. E, nestes trajetos noturnos, localizamos um dos pontos da relação com afins potenciais a partir do qual podemos colocar nosso ponto de vista para o presente ensaio: os bares indígenas presentes em algumas das aldeias na região5.

Para descrever o contexto das relações com os não indígenas, trago inicialmente aqui uma perspectiva bastante localizada e peculiar, que não "entra”, por assim dizer, na "bagunça”. Até mesmo porque considerar a "bagunça" como tal já nos localiza fora dela. Ela era colocada como tal por quem considerava reprováveis tais comportamentos. Mesmo assim, para falar da bagunça devemos entrar em perspectivas de uma antropologia noturna.

\section{Os bares e os trajetos na noite na aldeia}

Os pequenos bares em algumas das comunidades, especialmente nos fins de semana, representavam um lugar de relativo grande movimento. Nas noites, nas regiões mais centrais de certas aldeias, as caixas de som com músicas comerciais populares, sertanejos com temas românticos, funks com temas ambígua ou explicitamente sexuais, pareciam competir entre si e com as músicas, cantos e discursos de pastores das igrejas evangélicas ${ }^{6}$. Potentes aparelhos de som de algumas casas também eventualmente entravam nesta disputa. Por vezes mesmo durante o dia esses sons ecoavam na aldeia.

A maioria dos bares era bastante simples: um balcão atrás do qual eram oferecidos alguns produtos, sendo o principal as bebidas alcoólicas - cervejas, vermutes, conhaques e cachaças. Alguns também

5 Deixo a discussão sobre a "bagunça" em seus termos e consequências em relação ao casamento kanhgág e tensões com a monogamia e exclusividade sexual para outro artigo.

6 A presença evangélica, especialmente pentecostal, é bastante forte em boa parte das aldeias da região, por vezes chegando a contar com cerca da metade dos seus habitantes. 
ofereciam itens de consumo alimentar básico. Destacavam-se nos bares, além disso, as mesas de sinuca, que assim como as caixas de som funcionavam através de pequenas taxas. Eram sobretudo os homens que iam aos bares jogar e beber com os parentes e amigos. Eventualmente, homens indígenas e não indígenas bebiam e jogavam juntos, mas a situação mais comum era que esta distinção fosse notável, por se produzirem e reproduzirem ali as redes de sociabilidade. O dono do bar, por isso, às vezes cumpria um papel de mediador entre os frequentadores.

Há várias formas de beber. Nos bares se bebe com os amigos e parentes (especialmente afins efetivos), pagando eventualmente bebida para eles. Eram pontos de referência pelos quais indígenas e não indígenas passavam. Os indígenas que frequentavam estes bares eram não só jovens solteiros como também adultos casados. Podia-se perceber alguma relação entre a família extensa do dono do bar e os frequentadores, ainda que esta relação não fosse sempre colocada. Os não indígenas eram residentes nas redondezas, ou homens que tinham algum emprego em projetos mais ou menos temporários nas aldeias, como os derivados de projetos de compensação por empreendimentos. Em geral, dentro dos que cheguei a conhecer, tinham algum histórico de relações com os indígenas, inseridos no contexto local, ou cujo trabalho os inseria neste contexto por algum tempo. Alguns eram casados, outros não.

Mas os bares podiam ser apenas um ponto de passagem, um ponto intermediário em um trajeto da noite na aldeia, em um circuito mais amplo ${ }^{7}$, que, dependendo das intenções dos atores, pode envolver diferentes espaços para além dos bares: praça, campos de futebol, entre outros. Uma das intenções mais evidentes dos trajetos era o divertimento entre grupos de jovens indígenas, moças e rapazes, animados nestas circulações, e também as relações sexuais. Os bares eram lugares potencializados da troca de olhares, risos, conversa com indígenas e não indígenas, eram também ponto de passagem onde as potencialidades sexuais eram testadas e tentadas. Se nos circuitos indígenas há diferentes espaços para estas potencialidades no interior da aldeia, para os não indígenas, os bares poderiam resumir de maneira mais restrita estes circuitos.

Em várias situações pude ver alguns homens não indígenas que chegavam com seus carros em algum bar, trazendo com eles mulheres e rapazes indígenas, ou encontrando com estes ali, bebendo com eles ou apenas comprando para eles litros de bebidas, por vezes em grande quantidade, e partindo com ou sem as indígenas para outros locais. Alguns ficavam transitando de um bar a outro até ver onde estavam as indígenas que procuravam. Os rapazes que andavam com as moças incomodavam um pouco tais brancos, que, ao menos avaliando pelo que diziam, estavam interessados apenas nas mulheres. A presença destes rapazes, “amigos” (na verdade muitas vezes parentes também) das moças, parecia inibir, portanto, que as relações dos brancos com as indígenas se desenrolassem. De outro ponto de vista, parecia favorecer este jogo de seduções e interesses indígenas, de rapazes e moças, sem levar a relações sexuais com os brancos necessariamente.

As indígenas e os indígenas às vezes seguiam com estes brancos, percorrendo vários bares. Muitas vezes, porém, apenas bebiam com eles e se recusavam a continuar o trajeto. Assim, eu pensava que se tratava de uma estratégia para beberem e fazerem jogos de sedução com tais homens, aparentemente uma forma de diversão para as indígenas e os indígenas. Eu mesmo, neste ambiente bastante público do

7 Os conceitos trajeto e circuito são tomados da análise da antropologia urbana de José Guilherme H. Magnani (2008). 
bar, ainda que sem bebida e sem uma aproximação direta, não deixava de ser eventualmente atingido por olhares interessados seguidos de risos entre jovens.

Os trajetos dos jovens, no entanto, terminavam algumas vezes em pontos fora dos limites da Terra Indígena, seja na casa de algum destes não indígenas (mais raro) ou em outros pontos conhecidos nas proximidades, nas periferias das aldeias, como determinada árvore próxima a uma roça, ou certo local ao lado de tal ponto de referência. Estes pontos pareciam bastante dinâmicos e eu sabia deles muito pouco.

As circulações de grupos de indígenas pela noite eram menos dependentes dos bares, sendo mais comum que apenas passassem pelos bares para comprar bebida e seguissem para outros espaços, seja a praça central da aldeia, campos de futebol, eventualmente levando a lugares mais remotos como roças e beira da mata, ou mesmo outras aldeias próximas, a depender do contexto da noite. Essa circulação também pode se conectar a festividades públicas ou também às casas indígenas, em "bailes em casa" promovidos por seus residentes.

Os chamados bailes, que ocorrem em ocasiões públicas como festas de santo ou festividades cívicas como a semana do índio, entre outras, podem atrair diferentes participantes. Sua dinâmica varia bastante conforme quem as promove, seja a chefia ou certas famílias. Algumas, especialmente as promovidas pela chefia da aldeia, possuem um caráter de maior interação interaldeã, atraindo também regionais. Pode haver, então, várias noites seguidas de rodeios boiadeiros e bailes, estes últimos sempre com muita música, grupos musicais convidados, procurando agradar a diferentes gostos. Não raro, além dos espaços centrais dos bailes, há uma periferia deles onde, assim como nos bares, podem se iniciar caminhos para outras relações, incluindo sexuais, dentro dos circuitos de circulação, levando a outros espaços.

Outra situação são os "bailes em casa”, que soube ocorrerem em apenas algumas das TI da região. Eram feitos apenas eventualmente por certos indígenas, casados ou solteiros. Além de música e bebida, disseram-me haver relações sexuais bastante abertas entre presentes, incluindo extramaritais e seriais. Até onde soube estes bailes ocorriam exclusivamente com indígenas. Contrariavam frontalmente noções da monogamia e exclusividade sexual, sendo alvo de reprovações ${ }^{8}$.

A "bagunça", nesta perspectiva, vai do centro às periferias, até alcançar o exterior, ou então pode ir até os espaços mais íntimos, havendo atores que seguem tais trajetos e outros que vão apenas até determinado ponto. O "centro" da aldeia e os locais onde são eventualmente realizados bailes podem se tornar em alguns casos tão característico destes circuitos, como ponto de encontro de jovens para beber, conversar, paquerar, que famílias passam a tomar a inciativa de se mudarem para lugares mais afastados desses sons noturnos.

Considerando a perspectiva de uma espacialidade concêntrica cosmologicamente caracterizada pela tríade casa/limpo/mato virgem mencionada antes, teríamos a bagunça como algo transversal a estes espaços, ainda que se coloque de maneiras e tempos muito diferentes em cada um deles, sempre predominando o período noturno. Vai desde as casas, passando pelos bares, eventualmente chegando até os locais mais afastados, os espaços caracterizados pela maior alteridade, ou a afinidade potencial, na periferia da aldeia ou mesmo fora da TI, ainda que menos frequentemente ou apenas para certas

8 Este tema, que diz respeito mais às relações entre kanhgág, será trabalhado em maior detalhe em outro lugar. 
pessoas. Assim, a temporalidade da noite em alguma medida dobra, e oblitera em parte, a tríade, que, não obstante, podemos continuar percebendo como operativa de diferenças espaciais. Esta alteração é fonte estrutural de conflitos.

Várias pessoas mais velhas na aldeia criticavam tais comportamentos. Criticavam as circulações que, de dia, indicavam que os jovens não trabalhavam e à noite ficavam "bagunçando". Eventualmente procurava-se medidas junto à liderança da comunidade para evitar ou reduzir tais comportamentos.

Da perspectiva destas pessoas, o mundo jovem atual seria de predominante "bagunça”. Alguns mais velhos, viúvos ou separados, homens e mulheres, tinham até desistido de voltar a procurar esposas ou esposos, pois as mulheres novas não respeitavam mais os maridos, ou porque experiências de violência, traição e ciúmes os fizeram desistir da vida de casados. Um senhor, inclusive, sondou se eu conhecia índios da Amazônia ou em outras partes, pois ele achava que em outros lugares os "índios" podiam ser ainda como índios antigos. As índias podiam ainda respeitar os maridos. Ele disse estar disposto a aprender outra língua e abandonar suas roupas de "civilizado" se fosse o caso. Ou seja, a "bagunça” estaria generalizada e o modo de ser indígena só poderia ser alcançado alhures. Em um lugar de alteridade construído dentro de uma posição relacional em que o "índio puro" se coloca como possibilidade fora do mundo kanhgág. Coloca-se mesmo fora do mundo indígena conhecido, já que outras etnias locais também não representariam esta posição de "índio puro". Ali as "mestiçadas" não respeitavam mais o marido, não ajudavam mais no trabalho. Casar-se com mulheres neste contexto representaria uma transformação necessária no sentido "mestiço". A "bagunça” entra como aspecto que afastaria do ser indígena, aproximando-o do polo "branco".

Considerando o "mestiço" como uma construção histórica de uma posição de relação com a alteridade, representa aquele que se coloca entre um termo e outro. É uma posição que pressupõe um Outro além e um Outro aquém. Como mencionei, é posição relacional, ou seja, um ator pode ser mestiço em relação a um certo índio, e ser índio em relação a outro considerado como mais adiante em uma cadeia de transformações. Em nenhum caso temos posições fixas, havendo transformações ou reposicionamentos possíveis tanto em um como em outro sentido. E, assim, o que é "mestiço" hoje pode ser "índio" amanhã.

O bar, ponto de encontro com brancos, é também lugar que pode ser considerado como característico do comportamento não índio, mestiço. Podemos ver isso por os donos de bar poderem às vezes ser considerados "mestiços", desconsiderando sua relação de parentesco com indígenas. Podem prevalecer aspectos relacionados a sua própria condição de donos de bar, que além de mediador com brancos, propaga uma lógica de venda que contraria as relações esperadas do parentesco e generosidade. Suas casas, anexas aos bares, passam a ser referência da mestiçagem e branquitude nesta perspectiva. O bar seria o lugar próprio da mestiçagem e do encontro entre indígena e não indígena. Isto não significa que esta posição não seja ela própria mediada. Isto pode se dar, por exemplo, ao dono do bar vender fiado, havendo dívidas que sabidamente nunca serão pagas, que são perdoadas eventualmente, ou mesmo doações feitas seguindo lógicas de parentesco e relações sociais estabelecidas historicamente ou resgatadas a partir de critérios de pertencimento social. Se não pela via da consanguinidade egocentrada, via metades clânicas, ou mesmo pela histórica relação entre os indivíduos na Terra Indígena ou 
em trabalhos fora dela. Estas relações, quando necessário, são resgatadas ou (re)construídas através de discursos apropriados. Desta forma, mesmo alguém que tenha o bar como um lugar que cosmologicamente marca mestiçagem e queira se afastar desta posição, isso não impede de frequentar o local com alguma regularidade, ou até mesmo abrir um bar próprio, como era o caso do senhor que considerava a necessidade de casar com indígenas da Amazônia. Ele tentava a muito custo manter um ponto de venda, ainda que não vendesse bebidas alcoólicas, pois ele, além disso, era evangélico. Isto reforça a relatividade da consideração sobre a mestiçagem e a possibilidade de pensar o espaço do bar como também um espaço indígena, onde se reúnem afins efetivos e consanguíneos para se divertir, jogar, beber juntos, reforçando a consubstancialidade.

Neste sentido, poderíamos considerar o bar como expressão desta ambiguidade posicional, onde se pode indianizar o outro ou embranquecer-se. Ambiguidade típica dos lugares “entre”. Por isso um lugar de bastante potencialidade e também bastante perigo. Para perceber tais potencialidades e perigos, podemos observar o que algumas expressões sobre o ato sexual podem indicar, para depois retornar à relação com os não indígenas que ali frequentam.

\section{"Aproveitar" e "comer": o ato sexual e as posições relacionais entre os envolvidos}

Se o bar pode ser lugar de relação com afins potenciais e especialmente com não indígenas, em relação ao contexto mais ampliado da "bagunça" e de outros encontros possíveis, em outros locais, chamaram-me a atenção termos usados para caracterizar certas formas do ato sexual. Destaco as noções de "aproveitar" e de "comer".

Não é raro que um etnógrafo solteiro em campo receba propostas de casamentos ou se veja rodeado de comentários sobre estas possibilidades. Estas propostas podem representar tanto uma forma de estabelecer determinados tipos de relações com o estrangeiro como um modo de inseri-lo no contexto aldeão. Em meu caso, alguns homens chegaram a propor levarem mulheres para mim, para que eu as "aproveitasse". Isso ocorreu especialmente nas fases iniciais de meu campo durante o mestrado, mas também posteriormente em certas ocasiões quando chegava a estreitar novos laços com novos interlocutores, até mesmo no caso de uma liderança evangélica. Em algumas ocasiões fui colocado em situações que favoreciam isso, com ou sem bebida (pois logo optei por não beber com nenhum indígena), deixando-me em situações no mínimo constrangedoras.

A ideia de "aproveitar" também podia ser utilizada para jovens que nós chamaríamos de "homossexuais", termo este que não parece o mais apropriado. Um interlocutor designava os jovens que mantinham práticas homoeróticas em posição súcuba" como "machos-fêmea", destacando a distinção sexual dos papeis masculinos e femininos na definição de gênero. A posição íncuba do ato sexual entre homens não era considerada da mesma forma. Este mesmo interlocutor tratou em contexto jocoso da possibilidade de um homem se tornar macho-fêmea dizendo que sua cabeça poderia "virar”. Ele pró-

9 Opto por usar uma caracterização exógena súcubo/íncubo apenas para esclarecimento de forma sintética da atividade sexual. Além dos verbos "comer", "aproveitar" ou também "mexer" eram utilizados em significação próxima ao português usual "meter" e "dar", por exemplo. 
prio evitava qualquer contexto que pudesse favorecer tal abertura ao "virar", mesmo que fosse porque os outros pudessem assim pensar. Ele imediatamente mudava de comportamento, como se houvesse um risco de isto acontecer ${ }^{10}$. Também dizia temer casar com mulher que andava com "macho-fêmea" pois ela depois poderia ir embora com este. Isto indica a não permanência de "identidades" sexuais, colocadas muito mais em termos relacionais.

O "aproveitar" dá um sentido de consumo ao ato sexual, como se o papel feminino representasse um dispor sexual, havendo uma espécie de relacionalidade entre posição macho e fêmea, ou de masculino e feminino, que tal abertura ao "virar" indica. Neste caso, podemos comparar ao que coloca Orlando Calheiros (2015) ao tratar do desejo no contexto Aikewara no Pará. Segundo o autor, próprio do corpo masculino seria o desejo pela carne das mulheres e vice-versa, sendo este desejo construído nas brincadeiras desde a infância, constitutivo do próprio compor do corpo, levando a "estágios" de humano/animal, homem/mulher. Assim, entre os Aikewara também seria possível a existência de homens-mulheres, sendo que todos os homens seriam também em parte mulheres. $\mathrm{O}$ fundamental é que o desejo se dê pelo diferente, não algo próximo a mim. A alteridade, portanto, representada muito mais nos estados opositivos, mas intercambiáveis, é mais fundamental que as identidades, sendo também constitutiva dos corpos. A discussão lembra a da proposta da dividualidade de Strathern (2006), de um campo de dualidades no ser divíduo, campo este que é acionado e polarizado conforme as relações. No caso kanhgág, poderíamos colocar as posições de feminino/masculino como estágios relacionais mais do que definições prévias e fixas. Neste caso, o comportamento para com o outro parece mais indicador dos afetos de macho ou fêmea, ainda que sejam também ancorados na composição física, já que as posições cruzadas são caracterizadas por caráter duplo, "macho-fêmea", ao menos na perspectiva apresentada.

Sendo assim, temos um referente relacional ancorado no corpo. Lembrando proposições de Viveiros de Castro (1996), o ponto de vista estaria dado nos corpos, entendidos enquanto construídos pela cadeia afetiva multinatural. Neste sentido, a sexualidade estaria ancorada nos corpos enquanto suas agências afetivas. No entanto, o referente físico não é em todo caso necessariamente descartável; pelo contrário, ele pode aparecer na caracterização do duplo, a pessoa ocupando, portanto, ambas posições, vistas de pontos de referência diferentes (físico e afetivo), reunidas nesta perspectiva (macho-fêmea).

A alteridade envolta nas relações sexuais no caso kanhgág também se coloca na relação humano/ animal. Há relatos míticos que falam de pessoas que teriam tido relações sexuais com animais. Esta relação pode transformar a própria pessoa, seus afetos e seu físico. Assim, um homem que tinha relações com uma cadela passou, como um cão, a rodear antes de se deitar. Outro, que teve relações com uma égua teve um filho que, como cavalo, cresceu muito. Ou seja, não apenas a relação sexual pode modificar o ser entendido enquanto polo corpóreo-afetivo, como pode também ser uma relação frutífera, derivando em filhos que adquirem características de ambos pais, com humanidade de um, mas características físicas de outro. Voltarei às possibilidades de enlaces cósmicos interespecíficos adiante.

10 Inclusive sugeriu de maneira sutil que, solteiros ambos, não andássemos mais juntos sozinhos em áreas pouco movimentadas. 
A noção de consumo é ainda mais marcada no termo "comer". A noção do ato sexual como "comer”, nos remete à analogia entre estes dois atos que, como chamava atenção Lévi-Strauss (2006), seria presente em muitas sociedades. Usada também no português, ouvi ser empregada tanto para homens como para mulheres, que "comeriam" seus parceiros. Indica, assim, uma ambiguidade em relação ao ato sexual e as posições femininas e masculinas. Como me contava um interlocutor, sua avó tentava assustá-lo, e assim atrasar sua iniciação sexual, dizendo que as mulheres tinham dentes na vagina e iriam tentar comer seu pênis. Outro interlocutor comentou de um terceiro que chegou a comparar, de maneira evidentemente controversa, a mulher à criação (galinhas, porcos), como algo que se cria para comer, justificando desta forma ele próprio "aproveitar" a filha adotiva que havia criado. Apesar destas serem situações-limite, demonstram como o termo indica para uma noção de substancialidade e consumo do ato sexual. Destacando-se aqui termos dois sentidos do devorador/devorado em relação ao masculino e feminino. Em um caso focando-se na genitália e em outro na relação de criação. O sentido do "comer" significando a relação sexual tinha sujeito predominantemente masculino (o homem comeu a mulher), mas eventualmente ouvi narrações ao inverso (a mulher comeu o homem), neste caso especialmente quando é destacada a fogosidade da mulher. Além disso, em narrativas em que homens consideravam que mulheres não respeitavam monogamia, ouvi comentários conclusivos do tipo "mulher é bicho!", indicando também um sentido de animalização do feminino (outro). Sentido que reforça a noção de predação do ato sexual e a não humanidade do outro relacionada aos comportamentos sexuais.

A palavra em kanhgág é ko ${ }^{11}$ ou também konh há ou koko, que dão uma ideia de comer bem (algo bom, saboroso, em grande quantidade ou que se deseja bastante). $\mathrm{O}$ "comer", usado também em português, podia expressar a tensão sexual entre cunhados, ao se chamar um homem, em brincadeira entre afins, de "comedor de cunhada".

A noção de comer associada ao ato sexual, nos remete a uma noção de predação neste último. Mas, sem nos aprofundar nessa clássica discussão etnológica e psicanalítica, em kanhgág há outras expressões que conotam o ato sexual que também são possíveis neste contexto jocoso ou íntimo, como, por exemplo, a palavra tãpry, tradução possível do termo em português "trepar", na expressão $f i k r i$ täpry, ou seja, trepar em cima da mulher, como se trepa em uma árvore. Além disso, Wiesemann (2012) traduz como ato sexual a expressão jagnẽ mré nỹ, que indica uma mutualidade de relação entre duas pessoas (fazer um ao outro deitado), sendo que o termo jagnẽ pode ser usado em várias outras expressões que comunicam algum tipo de relação entre dois, desde a paz e a similaridade até a luta e oposição. Outra possibilidade apontada pela autora é a expressão mré nỹ (deitados juntos) ${ }^{12}$.

$\mathrm{O}$ ato sexual também pode ser pensado em seu caráter gerativo. Como me falava um interlocutor de cerca de 60 anos, a masturbação seria como "jogar fora” sua própria força. Os homens mais velhos tinham bastante resistência a usar camisinha, que eram distribuídas gratuitamente nos postos de saúde, sendo esta resistência bastante menor entre os mais jovens, em especial nas "bagunças" e "bailes em

11 Wiik (2004) também identifica termo similar para os Xokleng, grupo que junto aos Kaingang constituem os Jê meridionais. O verbo ko- expressaria tanto comer como fazer sexo e estaria relacionado ao estabelecimento de laços socio-afetivos e composição de alianças políticas.

12 O trabalho de Wiesemann é ligado ao Summer Institute of Linguistics e missões evangélicas, o que deve ser considerado nessas traduções mais próximas aos sentidos valorizados pela perspectiva cristã contemporânea, possivelmente em detrimento de outras expressões. 
casa" ${ }^{13}$. Esta noção gerativa e de força pode ser associada à noção de consumo que vimos antes. Outro interlocutor de idade similar disse que ejacular dentro do "plástico" (camisinha) seria equivalente ao ato de se masturbar, pois não teria "usado" a mulher. Ele especificou isto para o caso de mulheres profissionais do sexo. Elas sairiam rindo dos homens que lhes teriam dado o dinheiro de graça, sem as "usar". Este interlocutor destacava neste caso o medo do homem em ejacular. E a mulher como "macho" ao colocar este medo no homem. Ou seja, inverteria as posições de masculinidade e feminilidade do ato. Valeria, portanto, na posição masculina, aquele que prevaleceu ao consumir, usar, tirar algo do outro sem uma contrapartida equivalente. Temos também alterado o tema da vagina devoradora, referido às posições relacionais e não especificamente à genitália. Estes comentários indicam o interesse material feminino no ato sexual, apesar de ser focado na relação com mulheres não indígenas. Parece haver uma disputa da prevalência de perspectiva do ato, com a posição masculina neste caso sendo considerada dominante. Similar a quando se considera o "comer", com possibilidade de atribuição ao homem mas também à mulher como sujeito da ação.

As relações sexuais também estão envoltas em contrapartidas, o que não quer dizer trocas necessariamente equitativas. No caso kanhgág, esta contrapartida mais frequentemente é representada pela bebida. Ela teria uma dupla função, já que ao mesmo tempo que representa uma troca, também implica uma alteração dos estados de consciência, que, como vimos no contexto do bar, acompanha as relações sexuais na "bagunça”. Mesmo fora de contextos da "bagunça", especialmente entre casais mais jovens, a bebida está frequentemente presente nas relações sexuais, excetuados, ao menos discursivamente, os jovens evangélicos. No caso da "bagunça" a bebida representaria algo próximo à pescaria. Como um homem falava, ao ir pescar, que ia "pegar" e "comer a mulher do mandi" (uma espécie de peixe), fazendo metáfora cujo sentido está na ambiguidade do termo "comer" colocado junto à especificação "mulher de". A bebida seria uma espécie de isca que permite a captura na pesca. Este homem sugeria a mim que caso eu bebesse ou tivesse bebida em minha casa na aldeia (nesta época eu morava sozinho), mulheres e machos-fêmeas entrariam ali sem que eu precisasse fazer mais nada. No entanto, não sabia ele que em meu caso a bebida não era essencial para tanto. Um dia um rapaz, já alterado pela bebida, entrou em minha casa efetivamente. A filha de meu anfitrião, vendo isso, o fez sair dali, apesar de eu ter tentado estabelecer uma conversa amistosa com ele. Certa manhã me surpreendi também com algumas mulheres dormindo à minha porta após uma noite de bebedeira. Em outras ocasiões, à noite, outro rapaz também bateu à porta, uma vez já tendo bebido e outra não. Nem sempre, nestas situações, após longo tempo de permanência na aldeia, o "aproveitar" era algo que parecia tão distante, capturando minhas próprias perspectivas em favor de um contexto de pesca.

Estas colocações e situações indicam, de um lado, para a possibilidade de troca envolvendo sexo, com uma mutualidade ou mesmo companheirismo presente em algumas das expressões e, de outro lado, uma perspectiva predatória através do sexo. Vimos esta perspectiva predatória ou de consumo

13 Uma avaliação sobre o uso da camisinha entre os mais jovens necessitaria de uma análise mais detalhada, podendo relacionar-se à anticoncepção (a gravidez, especialmente para as mulheres, pode implicar em limitação à “bagunça”), mas também a outro caráter das relações nestas situações. Considera-se que a filiação se dá a partir de uma única relação sexual. Exames de DNA já passam a fazer parte das disputas em relação à paternidade, especialmente quando se vislumbra pensões alimentícias, mais característico em caso de pais não índios. Estas são situações raras entre pais indígenas, já que a adoção de crianças não desejadas pela mãe é comum. Os pais da moça ou algum outro parente frequentemente a ajudam ou adotam a criança quando não há casamento com o pai da criança. 
poder ser colocada tanto para homens como para mulheres. Nela o pressuposto da "troca" é evidentemente desigual quando não um engodo (considerando-se o ponto de vista masculino), e como destacarei adiante, o desejo passa por relações potencialmente alheias à "vontade" do sujeito. Estas duas alternativas, de mutualidade ou predação, não são incompatíveis entre si, pois a primeira também pode envolver a segunda, o que se reforça pela mútua asserção do comer, para homem e mulher. Nem sempre fica evidenciado haver uma relação muito desequilibrada. Em outros casos seria justamente o embate de qual perspectiva prevaleceria em relação ao ato sexual que se torna uma espécie de jogo "perigoso", destacado enquanto tal. Note-se que nem sempre a bebida precisa necessariamente estar envolvida, ou o fato de ter bebido às vezes já é suficiente para se colocar neste jogo e envolver nele terceiros.

A proposta de sexo como troca foi colocada por Siskind (1973), propondo a existência de uma troca de carne e sexo entre homens e mulheres, inserindo a autonomia feminina no esquema levistraussiano da troca. Retomando esta e outras contribuições sobre o tema, Vanessa Lea (1994; 1999), estudando o caso mẽbengokre, expande o interesse sexual das mulheres como derivado de um interesse em troca tanto por proteína como por bens manufaturados ou mesmo dinheiro. De maneira bastante diversa, Bruna Franchetto (1996) estudando o caso kuikúro e afirmando a autonomia feminina, propõe que o prazer feminino (que os modelos baseados na teoria da aliança tendem a ignorar) estaria muito mais em jogos de sedução, nos arrepios da clandestinidade e das brincadeiras que precedem a penetração, na excitação causada pelos bens dados como pagamento. Prazer e paixão estariam fora do domínio familiar e desvinculados da procriação. Assim, as mulheres, com bastante autonomia constituiriam um domínio de relações extraconjugais formando uma rede de trocas paralela, difusa e vital.

A partir de minha experiência entre kanhgág, tenho dificuldade em ver os domínios do desejo feminino como tão separados do domínio familiar, ainda que isto que Franchetto afirma possa eventualmente também fazer sentido, especialmente com relação às redes de trocas paralelas, extraconjugais. Sobretudo considerando os jogos de sedução com os não indígenas como veremos, haveria um certo prazer na sedução mesmo quando não implica em efetivação de relações sexuais. De outro lado, em relação à troca, mesmo que possamos considerar haver este interesse, ele pode se revelar ser uma relação desequilibrada, e, para além da relação de troca material, está colocada a possibilidade de relação com a alteridade, de afins potenciais (kanhgág ou não kanhgág) em um modelo invertível de predação.

Poderíamos considerar a sedução sexual como um aspecto da relação com a alteridade na qual o Outro representa destino (Viveiros de Castro 2002) em uma lógica de captura de forças exógenas. Algo semelhante à sedução estética produzida por certas mercadorias estrangeiras entre alguns grupos indígenas (Lagrou 2013). No caso sexual, teríamos uma aproximação neste sentido tanto no que diz respeito às substâncias corpóreas envolvidas na relação sexual, como também às contrapartidas potencialmente envolvidas nas trocas sexuais, seja bebida, dinheiro ou outras mercadorias. No caso kanhgág em análise, porém, temos algo mais complexo, visto que há possibilidades de transformações nos dois sentidos. No que tange às possibilidades sexuais e de casamentos, há bastante ambiguidade e caminhos diversos possíveis. Incluindo em especial as tendências indianizadoras do branco em algumas destas relações como veremos.

O que chamo a atenção aqui, mais do que o sexo como um dos elementos da troca, é que se constitui como elemento produtivo, no sentido de alterar relações entre Eu/Outro ou Nós/Outros. Elemento que, 
assim como a comensalidade, é um dos afetos fundamentais, seja como substancialidade produtiva, seja como definidor de perspectivas tanto de parentesco como de alteridade, incluindo e também para além do par feminino/masculino. Sempre estando em alguma medida presentes possibilidades do parentesco e alteridade no jogo da sexualidade, necessariamente alterados através do próprio sexo nestes jogos que ele envolve. Sexo como relação entre dois elementos, constitui ou polariza ambos. Neste sentido, nas análises acima, o aceitar a carne ou outros bens e oferecer sexo seriam relações que colocam em posição feminina o sujeito, ou ao menos posição feminilizada. Seria o caso dos "machos-fêmeas". Já no contexto da relação com o branco temos também a operação da oposição índio/branco. Em todo caso, temos sentidos que não estão dados de antemão na relação. Podendo um homem branco ser seduzido e comido, mesmo que tenha posição íncuba no ato. No sentido de que tem sua perspectiva capturada pela relação de predação. $\mathrm{Ou}$, ao contrário, podendo o indígena ser também capturado pela perspectiva não indígena.

Considerando ainda o desejo, e que o próprio ato traz a possibilidade "alimentar", ele também pode variar bastante entre as mulheres (assim como entre os homens). Assim, se os homens por vezes gavavam sua potência sexual, podendo manter sucessivas relações em uma noite, eram conhecidos em uma das aldeias em que trabalhei casos de mulheres sabidamente fogosas, levantando dúvidas se seus maridos conseguiriam satisfazer-lhes. Estas mulheres acabavam trocando de maridos com alguma frequência ou mantendo conhecidas ou supostas relações fora do casamento. Alguns índios diziam que apenas os brancos poderiam satisfazê-las, ou que nem brancos haviam dado conta delas. Em alguns casos isso implica que estas mulheres nunca se casem efetivamente, ou que após casamentos frustrados tivessem relações mais estáveis apenas por alguns períodos de tempo. Especialmente no caso de mulheres mais jovens, ao não se casarem podem passar a ser consideradas como mulheres "sem marido", "mén tũ".

\section{Mén tũ e relação com não indígenas}

Voltando agora aos bares, aos poucos fui notando que embora algumas moças passassem por ali, a maioria não se deixava levar muito longe com os homens brancos. Bebiam, conversavam com eles, mas continuavam andando em grupos. De algumas poucas, porém, inclusive de um pouco mais idade, eu ouvia dizer terem acompanhado alguns destes homens para espaços mais distantes e teriam relações sexuais com eles. Assim como saíam com eles, também seguiam por vezes com outros indígenas, tendo sido vistas por terceiros em locais próximos às matas, por exemplo.

Como notava Veiga (2000:104), mbédtũ, ou em outra grafia mén tũ, seriam mulheres "sem marido". Elas manteriam relações sexuais através de pagamentos. Isto existiria desde antes do contato mais intenso com brancos. Paola Gibram (2016), estudando o contexto da TI Rio da Várzea (RS), afirma que seriam mulheres que teriam optado por não casar devido ao contexto de agressividade masculina. Seriam mulheres "sem parentes", perdendo assim, sua marca e a condição de incesto a partir da regra exogâmica, superando assim o caráter de interdição e animalidade do incesto ${ }^{14}$.

14 É interessante destacar a diferença de atitude pressuposta para os pesquisadores e as situações limite que envolvem nosso posicionamento em campo. Ao contrário de mim, Gibram (2016) descreve a tensão em que era colocada como mulher, tendo que evitar andar sozinha ou estar sozinha com homens. Ela teve sua posição melhor estabelecida a partir de denúncia que fez ao cacique de um rapaz que chegou a sua casa à noite. Isso fez com que ela passasse a ser considerada como de respeito. Em meu caso, tal denúncia não faria sentido e, ao contrário, era pressionado a "aproveitar", como se minha posição sem isso fosse um tanto incompleta e ambígua sob certos pontos de vista. 
Assim, sobre estas mulheres em especial havia uma noção masculina de que bastava dar-lhes bebida para se ter relações sexuais. Eram poucas mulheres e bastante conhecidas. É como se elas representassem uma extensão do contexto da "bagunça" para a idade adulta. Elas, além de causarem ciúmes entre casais indígenas, também pareciam corresponder a certas pressuposições de não indígenas sobre as indígenas.

Assim como a noção de uma bagunça generalizada que tinham alguns indígenas, a ideia de disponibilidade sexual e de uma "promiscuidade indígena" parecia condizente com aquilo que alguns homens regionais esperavam. Os brancos regionais procuravam mais frequentemente justamente as indígenas marcadas por uma "liberalidade sexual" nos contextos de bagunça, e especialmente mulheres "sem marido", já que, apesar de "tentarem” as outras jovens solteiras, acabavam não conseguindo muito com elas.

Os brancos que procuram as indígenas e caem ou as levam, dependendo da perspectiva, em seus jogos de sedução e bebida também não são quaisquer brancos, e sim aqueles que frequentam regularmente as aldeias e têm alguns laços já estabelecidos. Trata-se, portanto, de pessoas conhecidas. Os próprios brancos mencionavam serem "estranhados" ao irem a bailes em outra aldeia, onde não frequentavam tanto e não conheciam bem os indígenas. Mesmo assim, tais homens, sem conhecer as redes indígenas de parentesco, podem cometer gafes ao investir em uma moça que esteja no bar quando um parente dela, irmão ou cunhado, esteja também ali, o que pode gerar alguma confusão. Um alerta do dono do bar ou de algum indígena mais próximo deles pode ser a salvação do desavisado. De qualquer forma, a concretização de uma relação sexual, pode levar bastante tempo, ou mesmo nunca passar dos jogos de sedução com os quais as mulheres conseguem bebida e se divertem. Por outro lado, não indígenas que buscam muitas mulheres, gerando conflitos com famílias, podem eventualmente ser "expulsos" pela liderança, não podendo retornar à comunidade. Vi isso ocorrer especialmente com brancos recém chegados à localidade.

Esta busca feita por não indígenas era reprovada por alguns. De certo ponto de vista indígena, podemos dizer que a hipersexualização seria característica do branco ${ }^{15}$. Ora, eram as "mestiçadas" que não "respeitavam" mais os esposos. Eram os brancos que vinham, aproveitavam das mulheres indígenas e iam embora. Eram os brancos que talvez pudessem satisfazer desejos de indígenas mais fogosas. Nesta perspectiva temos que a transformação no sentido do branco (mestiçagem) implica uma desconsideração às regras de casamento onde deveria prevalecer a manutenção conjugal e o respeito entre famílias. Neste caso, a "bagunça” representaria uma das vias desta transformação. A visão de generalização dessa bagunça, como vimos, faz deslocarem o indígena para outro espaço, a Amazônia, ou uma aldeia mais conservadora.

Por parte das mulheres, o interesse por estes homens poderia parecer ser mais imediato, garantindo uma noite de bebida e por vezes sexo, talvez sem as complicações que relações com indígenas podem envolver e experimentando uma corporalidade sexual distinta, sendo que a presença de um estrangeiro pode despertar olhares muito interessados. Mesmo entre jovens rapazes isso foi comentado a mim, dizendo que se fossem brancos como eu pegariam todas as índias ali, o que não podiam fazer sendo índios porque os pais delas já quereriam casá-los. Em outros casos me parece que a própria efetivação de casamentos com brancos parecia representar uma alternativa às dificuldades de se adequar a um modelo

15 Esta não é uma visão kanhgág para todos os contextos, pois alguns consideravam que os brancos não conseguiam ter relações sexuais consecutivas e não tinham seus pênis eretos, especialmente os maiores, tão rijos como os dos indígenas. 
de relações com os índios, ou mesmo de se efetivar relações desejáveis em um contexto visto como de "bagunça" e até violência potencial por ciúmes. O jogo de sedução, porém, tem na alteridade um elemento cosmologicamente produtivo, trazendo potencialidades de trocas de substâncias, mercadorias, implicando em potencialidades de transformação. Transformação esta que pode ter sentidos diversos.

\section{Bagunça, mestiçagem e indianização do branco}

A perspectiva de que os homens brancos, mesmo que conhecidos, procuram sexo e não têm respeito pode também se inverter. Se alguns homens me ofertaram mulheres para eu "aproveitar", uma mulher casada, por outro lado, veio me perguntar se eu não tinha interesse em me mudar definitivamente para sua aldeia, pois conhecia moças de lá que, vendo meu “jeito”, estariam interessadas em casar comigo. Diferente dos outros brancos que vinham aproveitar as índias e depois iam embora, eu estava "respeitando" a todos (e permanecendo bastante tempo na aldeia, comendo com os índios).

Indianização a rigor seria o caminho no sentido indígena na tríade indio puro/mestiço/branco. Indianizar pode expressar uma série de transformações contextuais e relacionais que aproximam do polo indígena, sem necessariamente gerar consanguinização e produção de parentesco. A comensalidade, como aspecto substancial, é elemento de grande relevância neste processo, e que se coloca entre a indianização e a consanguinização, uma vez que corpos que se alimentam conjuntamente se produzem ou são produzidos de maneira similar. $\mathrm{O}$ mesmo pode ser dito para a residência. De maneira similar, o sexo com suas trocas de substâncias se coloca nesta equação. Neste caso de forma ainda mais intensa quando gera descendência. O casamento, ainda mais, gera comensalidade, corresidência e descendência comum.

Em algumas aldeias, há casos de não indígenas que casaram com mulheres indígenas e passaram a morar na aldeia ou em suas proximidades, seguindo a regra indígena da uxorilocalidade. Ainda que tenha poucos dados sobre como se deram estes casamentos, podemos colocar que sua efetivação indica para formas bastante importantes de aproximação relacional do polo indígena. E o casamento representa a culminância de um processo de aproximações, precedido da residência próxima, por exemplo. Não significa dizer que tais brancos se tornem índios de maneira definitiva ou em termos essencialistas. Se tornam consanguíneos. A diferença quanto à indianidade é notada, e em certos sentidos a branquitude é irredutível. Não torna alguém mais índio que os demais índios ou mestiços, apenas em relação aos demais brancos. E a branquitude se perpetua na consideração da mestiçagem dos descendentes, em matizes e circunstâncias diferenciadas como exposto no início. Tais matizes da mestiçagem podem, por exemplo, depender do grau de indianização do pai e da indianidade mãe, se esta ensina a língua kanhgág ou prepara comidas de índio aos filhos e filhas, etc. Neste sentido o casamento e a consanguinidade não são garantias absolutas da indianidade, já que podem gerar transformações também no sentido inverso, nos casos em que a mãe deixe de fazer estas coisas.

Nestes processos transformativos é possível indicar o contraste de gênero. Homem indígena casar com mulher não indígena é algo mais raro e implica mudança para fora da aldeia. Segundo alguns interlocutores, não seria desejável, pois o homem não iria mais comer comida de índio, peixe assado, bolo de milho. Os conhecimentos e gostos culinários, portanto, conformam também o domínio da 
indianidade, sendo que mesmo a culinária de mulheres consideradas mestiças já apresentava diferenças notáveis aos homens. As mulheres, deste ponto de vista, teriam domínio da indianidade por esta via. Novamente vemos a consubstancialidade como definitiva nestas conformações de parentesco e possibilidades de aproximação entre índios e brancos, regulando passagens progressivas de uma posição a outra, ainda que não se possa falar em termos de identificação, mas de posições relativas.

As relações inclusive podem se tornar mais complexas, com casamentos sucessivos em famílias não indígenas com famílias indígenas, lógica de aliança também realizada entre famílias indígenas que cria fortes grupos políticos no interior das comunidades, mas que neste caso pode implicar residência longe da aldeia, mesmo de mulheres indígenas.

As relações com não indígenas, incluindo eventualmente aquelas da "bagunça", portanto, podem derivar em casamentos e descendência. No entanto, esta possibilidade é apenas um dos sentidos possíveis iniciados nas aproximações e jogos de sedução.

\section{Sexo e casamento no contexto da afinidade potencial}

O ingresso nos jogos de sedução pode fugir à nossas concepções possíveis do "desejo" enquanto vinculado a uma identidade e autonomia do ser. Conheci uma jovem kanhgág que tinha descartado a possibilidade de casamento com índios (exceto no caso de seu cunhado, de quem já engravidara duas vezes, sempre acusando o cunhado de a ter pego à força, com consequentes brigas familiares) pois os índios não trabalhavam e só queriam bagunçar. Ela parecia gostar de provocar alguns índios, especialmente os parentes de seu cunhado, procurando seduzi-los para depois refutá-los. Suas colocações, porém, eram ambíguas. Dizia estar apaixonada por um não indígena da região e ligou para ele vir buscá-la à noite na aldeia, mas em outra ocasião, de dia, fora da aldeia, fugiu dele apavoradamente. Fugiu igualmente de mim algumas vezes em que nos encontramos sozinhos, apesar de eu frequentar a casa em que ela morava, conversar com ela, comer sua comida. Mesmo com certa consubstancialização e a possibilidade de pensar em uma alteração dos afetos no sentido de se buscar uma alternativa não indígena de casamento, a potencialidade e o perigo da alteridade ainda se mantém e pode prevalecer no encontro de apenas dois.

A paixão que esta moça sentia pelo não indígena, descrevia ela, não tinha razão de ser, pois ele não fizera nada para ela gostar dele. Ela, porém, ficava dias pensando só nele. Associava o apaixonar-se também a um sofrimento, já adiantando este sentimento ao enamorar-se. Ora dizia que era louca por um, só pensando nele, depois dizendo que não gostava dele, que já o esquecera, temendo estar apaixonando-se por outro. O sentido predatório destas relações também aparecia, ainda que lateralmente, nos roubos de cigarro que ela fazia, tomando o cigarro das mãos de certos brancos ou indígenas e fugindo, ou fazendo com que os homens lhe dessem dinheiro, insinuando uma posterior relação sexual, que não se concretizava por ela fugir antes, e depois desconversando dizendo que não fora ela que "comera" o dinheiro e sim a máquina de som. Isto reforça a troca comensal expressa ou em bebida ou em dinheiro como contrapartida ao sexo, associada a uma perspectiva de pesca e engodos da sedução. 
Nas paixões desta moça, seu plano era de fugir com um desses homens, sendo que alguns deles eram casados com não indígenas. Ela pressupunha que eles largariam suas esposas por ela. No caso em que havia maiores chances de fuga (justamente o homem de quem certa vez "escapara"), ela chegava a imaginar como seria sua vida fora da aldeia, com os filhos que ela já tinha, não sendo cogitado o retorno de residência na aldeia ${ }^{16}$. Neste caso, é como se pudéssemos analisar as relações com afins potenciais como algo que captura os afetos da pessoa, levando-a a comportamentos ora de esquiva, ora mudança de perspectiva no sentido do outro, levando a uma consanguinização nos domínios da afinidade potencial.

Podemos contrastar as situações das mén tũ e da paixão e possibilidade de casamento vislumbrado com não indígenas com outras situações analisadas entre grupos indígenas das terras baixas, para pensar o que estas situações representam em nível cosmológico na relação com a alteridade e afinidade potencial.

Eduardo Nunes (2010) analisa uma aldeia karajá na cidade. Segundo o autor, lá os índios escolheram experimentar o casamento na lógica dos brancos, com um empenho em aprender a ser branco, efetuado da maneira indígena, isto é, pela mudança dos afetos, de perspectiva. Esta experimentação seria resultado de os Karajá em questão estarem procurando possuir uma duplicidade de perspectiva típica do xamanismo, com a possibilidade de adquirirem dois corpos, isto é, dois conjuntos de afetos distintos, e alternar entre eles. Já no contexto do alto Rio Negro, Lasmar (2005) aponta o casamento com branco como um processo de transformação. Na cidade de São Gabriel da Cachoeira, polo regional desta transformação, o conhecimento escolar, o viver na cidade e o casamento eram formas de contrabalancear a relação desequilibrada desde os primórdios míticos entre índios e brancos. Neste contexto, a alteridade entre etnias fica reduzida em relação à alteridade representada pelo branco.

Os jogos de sedução aparecem, como no caso das mulheres kuikúro na análise de Bruna Franchetto (1996), como domínio excitante da relação com a alteridade, onde as mulheres ${ }^{17}$ exercem autonomia, individual e coletivamente, controlando sua riqueza, seus corpos, seu sexo e estabelecendo alianças. Neste caso, alianças que podem dizer respeito aos conhecimentos cósmico-corpóreos da alteridade. No caso de São Gabriel da Cachoeira, a "putaria e saca”, espécie de caça aos homens feita pelas mulheres na cidade, através de canibalização contracoloniais, estaria justamente oposta à exploração sexual promovida pelos brancos (Olivar 2019). Ou seja, as formas mais desequilibradas de relação possuem também sua contraefetuação possível, na forma de uma captura ao inverso. Seria possível, assim, pensar o jogo de seduções, como uma forma de potencialização da agência feminina no estabelecimento de alianças, como já destacava Lasmar (2005). Os jogos de sedução, porém, ao mesmo tempo que representam a autonomia e possibilidade de captura do outro, como pontos de fuga também podem representar uma perda de autonomia e de perspectiva para uma relação que implica em afastamento no sentido da consanguinização em domínios afastados do parentesco indígena e mesmo plenamente humano.

16 A mãe da moça havia abandonando o pai na aldeia e sumido na cidade com não indígenas. Tanto o irmão como irmã da moça haviam casado com não indígenas. Podemos pensar, portanto, em uma tendência familiar, o que indica que essa alternativa não era apenas imaginada, mas efetivada em outros casos a despeito inclusive da reprovação do pai. Dada esta reprovação, o casamento neste caso implicaria fuga da moça para fora da aldeia ao menos temporariamente.

17 Pensando no caso kanhgág eu colocaria o feminino, visto que algo assim poderia ser considerado para mulheres e também para aqueles considerados macho-fêmeas. 
São jogos perigosos, especialmente quando envolvendo os domínios da afinidade potencial não previamente consanguinizada ou domesticada em alguma medida. A relação com os brancos implica relação com outras gentes, de perspectivas, substâncias e afetos muito diferentes e por isso trazendo riscos de uma transformação incontrolável, que faria com que se estranhasse os próprios parentes ao tornar-se branco em alguma medida. Esta transformação pode ser neutralizada ou revertida ao longo do tempo e especialmente através da descendência. Mas nem sempre isso parece possível ou garantido. E quanto menos consanguinizado, maiores parecem estes perigos e incertezas.

Neste sentido, coloca-se a associação de um personagem de outro mundo com homem branco. O boto, conhecido na Amazônia como ser que seduz e engravida mulheres, levando-as para seu mundo subterrâneo, aparece como um belo e elegante branco galanteador. Ele faz as mulheres se apaixonarem perdidamente por si, e esta paixão as leva para o fundo do rio, fazendo com que adoeçam e morram, podendo levar também seus parentes nesta viagem sem retorno, para um mundo onde viveriam uma sexualidade sem restrições. O boto é associado ao abandono dos parentes, sendo ditado característico a associação de filhos sem pai conhecido como "filho do boto", indicativo também de mestiçagem, de um modo de viver mestiço e um modo de relacionar-se sexualmente (Lasmar 2005; Belaunde 2015b).

O sexo com seres do cosmo também é presente entre os kanhgág, para além dos casos míticos mencionados antes. Um dos caminhos do conhecimento xamânico é o estabelecimento de uma relação com duplo de animal da mata virgem, ou seja, domínio de alteridade radical (Cimbaluk 2018). É relação tão perigosa como aquela com o boto na Amazônia e pode implicar em consequências similares no caso de não ser controlada. Ou seja, encontros na mata com espíritos animais por pessoas que não sejam mestres nos trânsitos entre perspectivas podem fazer com que a pessoa seja levada para sempre por eles (Nimuendajú 1993). As pessoas que conseguem controlar estes trânsitos se tornam kujá, e esta relação toma o potencial xamânico, com o guia indicando remédios do mato virgem e levando o kujá a lugares do cosmos onde se perderam espíritos dos vivos. Estas relações são sempre muito peculiares e possuem suas próprias idiossincrasias. As relações com este duplo, guia animal, se dá com um ser de sexo oposto ao do xamã, aparecendo sob a forma humana, e tem conotação de casamento, podendo chegar a relações sexuais. Como nota Rogério Rosa (2011), a relação entre kujá e seu guia, jagrẽ, pode ser marcada pelo ciúme e disputas com o cônjuge humano. Esta relação, porém, se dá com guia da mesma metade que o kujá, e, ao que sei, não gera descendência. São relações no contexto de alteridade potencial característico da mata virgem, que têm como marca sua infertilidade em termos de descendência, e contravenção em termos das regras sociais. A relação com os jagrẽ pode ainda remeter a uma anti-socialidade humana a partir de uma alteração de perspectiva relacionada aos domínios mais exteriores. Transgride regras do casamento e produção do parentesco a partir da exogamia de metades e não teria em vista a produção de parentesco e parentes.

Há também explicações para comportamentos dos "bagunceiros" de caráter cosmológico. Sob certas perspectivas, não apenas os kujá, mas todos os kanhgág teriam guias espirituais (jagrê), não tendo neste caso uma conotação de relação conjugal, mas algo como um espírito acompanhante. Afirma-se assim que as pessoas "bagunceiras" teriam como guia espiritual espíritos "maus", "ruins” (jagrẽ kórég) ou então seriam influenciadas por espíritos maus atraídos por seu próprio comportamento errático, com 
um mútuo reforço. Outra explicação possível era a da feitiçaria. No próprio caso da moça que descrevi, seu pai a levou a curadores regionais não indígenas, que indicaram que a moça vinha sofrendo por algo que outro indígena tinha feito a ela, fazendo com que ela saísse para circular à noite na aldeia (para perspectivas nestes sentidos ver Cimbaluk 2018: 146; 2019). Estas noções aproximam ao que Wiik (2004) postula para os Xokleng, com uma tradução ao sentido cristão da influência diabólica, similar ao que havia também entre kanhgág evangélicos.

Assim podemos ver que as relações no âmbito da afinidade potencial, localizadas cosmologicamente em um espaço exterior da mata virgem ou de outros contextos extra aldeãos como a cidade, podem remeter a um grande risco ao mesmo tempo que uma grande potencialidade, expressa não em termos de fertilidade, mas de outras formas de potência. Poderíamos dizer que a associação da bagunça com os espíritos "ruins" (kórég) explicita a noção de que a "bagunça” estaria em relação contrária à própria fertilidade. Ainda que efetivamente a bagunça seja um dos meios de estabelecimento dos casamentos usuais entre indígenas kanhgág. Seria tolerável sob certos pontos de vista, desde que se encerrasse quando do primeiro filho da mulher, levando então ao casamento.

Parece-me que as mulheres "bagunceiras" e aquelas e aqueles kanhgág que buscam casamento ou relações sexuais com brancos, podem ter nesta busca de experimentação posições e intensidades distintas em relação à transformabilidade relacional com a alteridade, e daí sua intrigante potência e caráter sedutivo. Quando se coloca o desejo de se ter casamento com brancos, é por eles serem mais trabalhadores que os índios, e terem mais dinheiro e mercadorias. Neste caso, é possível pensar o jogo de seduções como uma forma de potencialização da agência feminina a partir das possibilidades de troca. Mas vimos que mesmo nestes casos não são sempre decorrentes de uma "vontade" clara da mulher, podendo representar, ao contrário, espécie de captura, uma perda de ponto de vista decorrente de um jogo de seduções.

O sexo pode se aproximar à alimentação e predação, que se reforça pela predação poder ser colocada tanto para homens como para mulheres, dando um caráter de mutualidade a ela, sem necessariamente levar ao casamento. Se podemos aproximar a questão da predação à relação com a alteridade, tal tipo de relação se exacerba na relação com os brancos. Isto pela posição dos brancos fora das redes de parentesco, hipersexualidade, e pelo sexo não implicar as complexas relações intra e interaldeias, sendo uma posição contra as redes de parentesco. Favorece tal desfrute, que permite ir além da liberalidade sexual em um processo de passagem, e permitindo estabelecer uma forma de relação com a sedutora e potencializada, aparentemente opulente, alteridade radical da afinidade potencial, sem procurar neste movimento necessariamente a produção de parentesco. Há a relação que envolve a "troca" de bebida e sexo, mas ela não é necessária, e ao mesmo tempo a bebida pode ser uma isca. É o jogo de seduções e captura que parece central na apreensão da alteridade do outro, em um perigoso e intrigante dar-se para capturar o outro, disputando-se a prevalência de perspectivas, de maneiras nem sempre tão bem controladas, especialmente se efetuadas de maneira individualizada, sem a companhia dos parentes que asseguram que não se irá perder a perspectiva para o outro. Tanto mais quanto menos conhecido e consubstancializado seja este outro. Um tal deslocamento de perspectivas redundaria na impossibilidade de manutenção da relação e a visão de ter-se perdido a própria subjetividade ou ponto de vista, no caso 
de ter-se podido recuperá-la posteriormente ainda que transformada. Caso contrário, seria uma efetiva transformação dos afetos do sujeito.

São relações perigosas. Como se ao dar-se a capturar para poder capturar o outro já se estivesse implicado e implicando o outro na relação presa-caçador ou pescado-pescador, podendo gerar consequências às vezes não "desejadas" previamente por talvez nenhum dos envolvidos. Como se a relação de alteridade, a mútua implicação pescado-pescador, pudesse superar seus elementos individuais. E neste sentido, ela pode ser guiada por "outros" dos próprios envolvidos, jagré kórég ou seres demoníacos. $\mathrm{Ou}$ ainda orientada por serviços de feitiçaria. Podemos considerar uma relação de troca, que desloca o Outro, captura-o, por assim dizer, ao mesmo tempo que abre a possibilidade de captura da perspectiva do sujeito por Outros.

O processo de aproximação que os não indígenas passam até chegar às possibilidades mais efetivas de relação parece fazer com que também eles se coloquem sob risco de perderem ou terem transformadas suas perspectivas e afetividades. Tanto maior quanto mais trocas e consubstancialização por outras vias forem estabelecendo com indígenas na aldeia. Mas a simples presença de um não indígena nestas situações, devido a suas às vezes insuspeitas potências, coloca ele e alguns de seus outros nesta relação pesca-pescador, envoltos ambos no contexto dos jogos de sedução e do "aproveitar". Mesmo sem bebida ou oferta de qualquer troca, a captura pode se dar, para um lado e/ou para o outro, pressupondo-se as possibilidades de uma efetivação da afinidade, mesmo que controversa ou não aceita socialmente.

Podemos considerar um desejo pela mudança de perspectiva em termos próximos aos xamânicos, guardadas as proporções dos graus de alteridade envolvidos. Assim seria a perspectiva das mulheres "bagunceiras" e "mén tũ" que flertam ou têm relações mais frequentes com os brancos sem casamento e sem perderem-se e serem levadas efetivamente por eles. Ela parece bastante mais próxima, em grau diferente, ao xamanismo no sentido da busca por um conhecimento experimental (no sentido de ser experimentado) com pessoas que representam polo de alteridade carregado de potências. Parecem ser a ponta de lança, não necessariamente "intencional", do movimento de consanguinização e potencial produção de parentesco. Assim como no caso xamânico, são capazes de atrair potências Outras e, aos poucos, torná-las também indígenas. Ainda que seu "peixe” possa escapar ou roubar-lhes a isca. Ao que tudo indica, conseguem fazer isso em alguns casos sem uma perda irreversível de perspectiva, ainda que de certos pontos de vista já sejam "mestiçadas”.

A defesa do casamento, em especial o monogâmico, pode representar o oposto a estes perigos. No caso do senhor que queria casar com uma índia da Amazônia, seria a tentativa de efetuação de casamentos com estrangeiros através de projeção de um indígena no lugar da alteridade, um índio estrangeiro, dada a aparente inviabilidade, na perspectiva do ator, em realizá-lo no contexto intraétnico. Quando do ponto de vista do ator os indígenas ali só bagunçam e não trabalham, são tudo "mestiçada”. Um índio de outra aldeia, outra etnia, um "índio" desconhecido de terras longínquas, poderia cumprir este papel de uma alteridade ideal, indígena. Diferente do caso da "bagunça”, a relação envolveria uma mudança efetiva, com afastamento da comunidade, e a mudança de hábitos, de língua, de moradia, de roupas, de comidas, de trabalho. Neste caso, ao inverso do caso de que trata Nunes, é para efetivar uma relação kanhgág (de "índio puro"), aceitável e plena na perspectiva do ator, que seria necessário 
contrariar outros elementos afetivos kanhgág, mesmo o de casar com kanhgág. Com o polo da alteridade sendo um indígena não kanhgág ainda desconhecido. Seria o oposto do caso das paixões por não indígena, quando a opulência e suposta ética de trabalho atraem à mudança de afetos no sentido não indígena. Nos dois casos, transformar-se-iam radicalmente os afetos da mesma forma. Em um caso renunciando aos jogos de sedução da "bagunça" "mestiça”, em outro acedendo a eles perigosamente, em uma negação da "bagunça" branca. São situações limite, por vezes vivenciadas mais como expectativa que como efetividade. Mas permitem pensar em transformações no sentido do outro que podem representar interessantes potencialidades, incluindo no sentido da abundância e do respeito, resultando em novas alianças.

Em todo caso, a "bagunça" seria como uma contraefetuação da monogamia e exclusividade sexual. Com o desfrute sexual reforçando um modelo de predação mútua plural, possível tanto com o indígena kanhgág como com o não indígena, representando em cada caso intensidades distintas na relação com a alteridade e possibilidades de controle e neutralização ou não através da subsequente construção do parentesco. Mas, ao que parece, é a oposição a ela que representa uma maior abertura potencial à mudança deliberada dos afetos.

\section{Lucas Cimbaluké Doutor em Antropologia Social pela Universidade Federal de Santa Catarina (UFSC) e antropólogo do Instituto do Patrimônio Histórico e Artistico Nacional (IPHAN).}

\section{REFERÊNCIAS BIBLIOGRÁFICAS}

ALMEIDA, Miguel Vale de. 2003. “Antropologia e sexualidade: consensos e conflitos teóricos em perspectiva histórica”. Pp.53-72 in A sexologia, Perspectiva Multidisciplinar, org. L. Fonseca, C. Soares e J. M. Vaz. Coimbra: Quarteto, vol.II.

BELAUNDE, Luisa Elvira. 2015a. "O estudo da sexualidade na etnologia”. Cadernos de Campo 24: 399-411.

BELAUNDE, Luisa Elvira. 2015b. "Resguardo e sexualidade(s): uma antropologia simétrica das sexualidades amazônicas em transformação”. Cadernos de Campo 24: 538-564.

CALHEIROS, Orlando. 2015. "O próprio do desejo: a emergência da diferença extensiva entre os viventes (Aikewara, Pará)”. Cadernos de Campo 24: 487-504.

CIMBALUK, Lucas. 2013. A Criação da Aldeia Água Branca na Terra Indígena Kaingang Apucaraninha: "política interna", moralidade e cultura. Dissertação de Mestrado, Programa de Pós-graduação em Antropologia Social, Universidade Federal do Paraná.

CIMBALUK, Lucas. 2018. Nügme to ẽpry há, Kanhkã to épry kórég: caminhos kanhgág entre bem e mal. Tese de Doutorado, Programa de Pós-graduação em Antropologia Social, Universidade Federal de Santa Catarina. 
CIMBALUK, Lucas. 2019. "Xamanismos kanhgág: as artes de Pedro 'Chapéu Branco”. Espaço Amerindio 13(2): 211-241.

CRÉPEAU, Robert. 1997. "Les Kaingang dans le contexte des études Gé et Bororo”. Anthropologie et Sociétés 21(2-3): 45-66.

FRANCHETTO, Bruna. 1996. "Mulheres entre os kuikúro”. Estudos Feministas 4(1): 35-54.

GIBRAM, Paola Andrade. 2016. Penhkár: politica, parentesco e outras histórias kaingang. Curitiba: Appris; Florianópolis: Instituto Nacional de Pesquisa Brasil Plural.

LAGROU, Els. 2013. "Chaquira, e inka y los blancos: las cuentas de vidrio en los mitos y en el ritual kaxinawa y amerindio." Revista Española de Antropología Americana, v.43, n.1: 245-265.

LASMAR, Cristiane. 2005. De volta ao Lago de Leite: gênero e transformação no Alto Rio Negro. São Paulo: Editora UNESP; ISA; Rio de Janeiro: NUTI.

LEA, Vanessa. 1994. "Gênero feminino Mebengokre (Kayapó): desvelando representações desgastadas". Cadernos Pagu 3: 85-115.

LEA, Vanessa. 1999. "Desnaturalizando gênero na sociedade Mêbengokre”. Estudos Feministas 7 (1 e 2): 176-194.

LÉVI-STRAUSS, Claude. 1982. As estruturas elementares do parentesco. Petrópolis: Vozes. LÉVI-STRAUSS, Claude. 2006. A origem dos modos à mesa. São Paulo: Cosac Naify.

MAGNANI, José Guilherme C. 2008. "Quando o campo é a cidade: fazendo antropologia na metrópole”. In: Na Metrópole: textos de antropologia urbana, org. J. G. Magnani. São Paulo: Edusp; Fapesp.

MALINOWSKI, Bronislaw. 1932. The sexual life of savages in North-Western Melanesia. Londres: George Routledge \& sons.

MALINOWSKI, Bronislaw. 2013. Sexo e repressão na sociedade selvagem. Petrópolis: Vozes.

MCCALLUM, Cecilia. 1994. "Ritual and the origin of sexuality in the Alto Xingu”. Pp. 90-114 in Sex and Violence: Issues in representation and experience, ed. P. Harvey e P. Gow. London; New York: Routledge.

MCCALLUM, Cecilia. 2013. "Intimidade com estranhos: uma perspectiva kaxinawá sobre confiança e a construção de pessoas na Amazônia”. Mana 19(1): 123-155.

MEAD, Margaret. 1979. Sexo e temperamento. São Paulo: Perspectiva.

NIMUENDAJÚ, Curt. 1993 [1913]. Etnografia e indigenismo: sobre os Kaingang, os Ofaié- Xavante e os indios do Pará. Campinas: Ed. da UNICAMP.

NUNES, Eduardo S. 2010. "O pessoal da cidade: o conhecimento do mundo dos brancos como experiência corporal entre os karajá de buridina”. In: Conhecimento e cultura: práticas de transformação no mundo indígena, ed. E. C. Lima e M. Souza. Brasília: Athalaia.

OLIVAR, José Miguel Nieto. 2019. "Caçando os devoradores: agência, 'meninas indígenas' e enquadramento neocolonial”. Revista de Antropologia 62(1): 7-34.

PISSOLATO, Elizabeth. 2015. "Fuga como estratégia: notas sobre sexualidade, parentesco e emoções entre pessoas mbya". Cadernos de Campo 24: 412-426. 
ROSA, Patrícia Carvalho. 2011. "Para deixar crescer e existir": sobre a produção de corpos e pessoas kaingang. Dissertação de Mestrado, Universidade de Brasília.

ROSA, Rogério Reus Gonçalves da. 2011. "Mitologia e xamanismo nas relações sociais dos Inuit e dos Kaingang”. Espaço Amerindio 5(3): 98-122.

SEEGER, Anthony; DA MATTA, Roberto; VIVEIROS DE CASTRO, Eduardo. 1979. "A construção da pessoa nas sociedades indígenas brasileiras”. Boletim do Museu Nacional 32: 2-19.

SISKIND, Janet. 1973. To Hunt in the Morning. Oxford: Oxford University Press.

STRATHERN, Marilyn. 2006. O Gênero da Dádiva. Campinas: Ed. da Unicamp.

VEIGA, Juracilda. 1994. Organização Social e Cosmovisão Kaingang: uma introdução ao parentesco, casamento e nominação em uma sociedade Jê Meridional. Dissertação de Mestrado, Universidade Estadual de Campinas.

VEIGA, Juracilda. 2000. Cosmologia e práticas rituais Kaingang. Tese de doutorado, Universidade Estadual de Campinas.

VIVEIROS DE CASTRO, Eduardo B. 2000. "Atualização e contra-efetuação do virtual na sociedade amazônica: o processo de parentesco". Ilha 2(1): 5-46.

VIVEIROS DE CASTRO, Eduardo. 1996. “Os pronomes cosmológicos e o perspectivismo ameríndio". Mana 2(2): 115-144.

VIVEIROS DE CASTRO, Eduardo. 2002. "O mármore e a murta: sobre a inconstância da alma selvagem”. In: A Inconstância da alma selvagem. São Paulo: Cosac Naify.

WIESEMANN, Ursula Gojtéj. 2012. Kaingang-Português; Português - Kaingang: Dicionário. Curitiba: Editora Evangélica Esperança.

WIIK, Flávio Braune. 2004. Christianity converted: an ethnographic analysis of the xokleng Laklanõ indians and the transformations resulting from their encounter with pentecostalism. Doctoral dissertation, University of Chicago. 


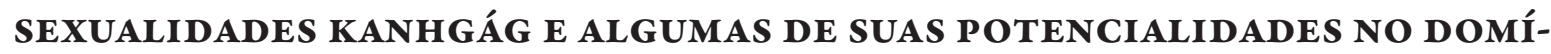 NIO DA AFINIDADE POTENCIAL
}

Resumo: Este trabalho procura explorar alguns aspectos da sexualidade kanhgág. Tem como base experiências bastante particulares observadas e vivenciadas em campo, em Terras Indígenas no norte do Estado do Paraná. Esboça algumas possibilidades analíticas a respeito de relações indígenas no domínio da afinidade potencial, especialmente a não indígena ou não kanhgág. Situações que contrastam com as do domínio familiar e da afinidade efetiva, constituídas por consubstancialização e filiação. Tratando do contexto de "mestiçagem" e "bagunça" na avaliação dos comportamentos sexuais, analisa como certas situações vão contra processos de consanguinização, implicando ou devir outro deliberado ou a capacidade de trânsito entre pontos de vista diferentes implicados nas relações sexuais.

Palavras-chave: Sexualidade indígena; construção do parentesco; mestiçagem; Kaingang.

\section{KANHGÁG SEXUALITIES AND SOME OF ITS POTENTIALITIES IN THE DOMAIN OF POTENTIAL AFFINITY}

\begin{abstract}
This work seeks to explore some aspects of kanhgág sexuality. It is based on particular experiences observed and lived in the field, in Indigenous Lands in the north of the State of Paraná. It outlines some analytical possibilities for indigenous relations in the domain of potential affinity, especially non-indigenous or non-kanhgág. Situations that contrast with the family domain and effective affinity, constituted by consubstantialization and filiation. Approaching the context of miscegenation and "bagunça" in the evaluation of sexual behaviors, it analyzes cases that go against the processes of consanguinization, implying or deliberate becoming other or an ability to transit between different points of view involved in sexual relations.
\end{abstract}

Keywords: Indigenous sexuality; kinship construction; miscegenation; Kaingang.

RECEBIDO: $20 / 05 / 2020$

APROVADO: $21 / 10 / 2020$ 
188 CAMPOS V21 N.1 p. 163-187 jan.jun.2020 